\title{
Health risk assessment of selected metals through tap water consumption in Upper Silesia, Poland
}

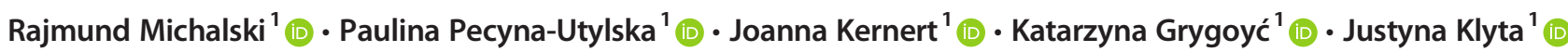

Received: 28 April 2020 / Accepted: 20 October 2020 / Published online: 31 October 2020

(C) The Author(s) 2020

\begin{abstract}
The research focused on assessing the risk to human health resulting from the content of selected $\mathrm{Cr}, \mathrm{Co}, \mathrm{Mn}, \mathrm{Cu}, \mathrm{Ni}, \mathrm{Pb}, \mathrm{As}, \mathrm{Zn}$ and $\mathrm{Sr}$ metals in tap water supplied by Upper Silesia Water Plant to the inhabitants of the Upper Silesia region (Poland). It is the main supplier of drinking water to several million inhabitants of this agglomeration. Samples were taken and analyzed quarterly in 2019. The sampling points were chosen to help identify the source when an elevated level of a particular contaminant is observed. ICP-MS and ICP-OES have been used to measure the concentrations of those elements. The chronic daily intake (CDI), hazard quotient (HQ) and hazard index (HI) results for non-carcinogenic risk assessment of metals in tap water has been assessed. CDI values of non-carcinogenic metals were higher in children than in adults; the CDI values for adults and children were found in the order of: $\mathrm{Zn}>\mathrm{Sr}>\mathrm{Cu}>\mathrm{Mn}>\mathrm{Ni}>\mathrm{Pb}>\mathrm{Cr}>\mathrm{Co}>$ As. All the studied metals had HQ values below 1, the risks caused by the non-carcinogenic metals decreased in the following order: $\mathrm{Zn}>\mathrm{Cu}>\mathrm{Co}>\mathrm{As}>\mathrm{Sr}>\mathrm{Pb}>\mathrm{Cr}>\mathrm{Ni}>\mathrm{Mn}$. HI values were also less than 1, that meaning that the analyzed tap water is safe for human consumption. The concentration of $\mathrm{As}, \mathrm{Cr}, \mathrm{Cu}$, $\mathrm{Mn}$ and $\mathrm{Ni}$ in analyzed tap water is in accordance with Polish and international requirements.
\end{abstract}

Keywords Tap water $\cdot$ Metals $\cdot$ Health risk assessment $\cdot$ Upper Silesia $\cdot$ Poland

\section{Introduction}

Assessment of the human health risk comprises qualitative and quantitative evaluation of the human's exposure to contamination originating mainly from environment and food, in particular in drinking water. The quality of water consumed has a strongly impact on our health and well-being. Human life strongly depends on the quality drinking water intake required to prevent any risks to human health. The consumption of water containing a certain amount of some metals may lead to health problems such as cancer in humans $[1,2]$. Some metals and metalloids such as zinc, iron, selenium cobalt, copper, chromium, vanadium, or molybdenum are essential elements for the growth and reproduction, but their accumulation in excess in the human body is undesirable. In turn, nonessential metals such as lead and cadmium having no positive role in the metabolic activities can cause toxic effects on the

Rajmund Michalski

rajmund.michalski@ipis.zabrze.pl

1 Institute of Environmental Engineering, Polish Academy of Sciences, Zabrze, Poland body tissues [3]. Thus, it is extremely important to obtain reliable results in all laboratories involved in drinking water analysis [4].

Metals and metalloids have been determined with classic and instrumental methods. Classic methods are usually laborintensive, require toxic chemicals, and often they do not provide full automation. When spectrometric methods appeared, the classic metal determination methods started to lose their significance [5]. At present, they have been nearly completely replaced with the instrumental methods including hyphenated techniques $[6,7]$.

The quality of drinking water is regulated at national and international levels $[8,9]$.In Poland it is Regulation of the Minister of Health from December 7th, 2017 [10]. Limit values for selected metals and metalloids as well as $\mathrm{pH}$ and conductivity recommended by WHO, US EPA and Polish regulation are given in Table 1 . Tests for the quality of drinking water are carried out by specialized laboratories in accordance with the requirements described in the relevant regulations. Nevertheless, consumers are sometimes dissatisfied with the quality of tap water, primarily because of its taste, color or smell. In addition, they indicate that the composition of water in the water plants may be different than in the tap 
Table 1 Limit values for selected parameters in drinking water

\begin{tabular}{llll}
\hline Parameter & WHO [8] & US EPA [9] & Polish regulation [10] \\
\hline $\mathrm{Cr}$ (total), mg/L & 0.05 & 0.1 & 0.05 \\
$\mathrm{Co}, \mathrm{mg} / \mathrm{L}$ & - & - & - \\
$\mathrm{Mn}, \mathrm{mg} / \mathrm{L}$ & 0.4 & - & 0.05 \\
$\mathrm{Cu}, \mathrm{mg} / \mathrm{L}$ & 2.0 & 1.3 & 2.0 \\
$\mathrm{Ni}, \mathrm{mg} / \mathrm{L}$ & 0.07 & - & 0.02 \\
$\mathrm{~Pb}, \mathrm{mg} / \mathrm{L}$ & 0.01 & 0.015 & 0.01 \\
$\mathrm{As}, \mathrm{mg} / \mathrm{L}$ & 0.01 & 0.01 & 0.01 \\
$\mathrm{Zn}, \mathrm{mg} / \mathrm{L}$ & - & - & - \\
$\mathrm{Sr}, \mathrm{mg} / \mathrm{L}$ & - & - & - \\
$\mathrm{pH}$ & $6.5-8.5$ & $6.5-8.5$ & $6.5-9.5$ \\
$\mathrm{Conductivity}, \mu \mathrm{S} / \mathrm{cm}$ & - & 2500 & 2500 \\
\hline
\end{tabular}

water, mainly because of water transfer systems [11]. It may results from sedimentation of the some contaminants, especially metals by corroding the water pipes and the washing-up through the water distribution system pollutes the tap water. The used materials in the household piping are transferred to the drinking water through the contacting corrosive water with pipes, valves, fittings, as well as municipal and domestic distribution networks. Due to the importance of this issue, several studies have been conducted to investigate the chronic health effects of exposure to metals from drinking water consumption worldwide $[12,13]$.

In Poland around 8700 plants producing drinking water exists, of which over $90 \%$ of them small are water plants, producing up to $1000 \mathrm{~m}^{3}$ of water per day. The largest of them - Upper Silesia Water Plant - is located in Katowice and supplies drinking water to several million inhabitants of this agglomeration. The population density is the highest in Poland and one of the highest in Europe, negatively contributing to the irreversible changes in the environment. It is a highly developing industrial region, with many hard coal mines, cookeries, heat and power plants, and steel works - all of these having a negative impact on the environment, including the quality of surface and groundwater $[14,15]$.

The aim of the study was to assess the content of selected metals ( $\mathrm{Cr}, \mathrm{Zn}, \mathrm{Co}, \mathrm{Mn}, \mathrm{Cu}, \mathrm{Ni}, \mathrm{Pb}, \mathrm{As}, \mathrm{Sr}$, and $\mathrm{Zn}$ ) in drinking water collected at 18 points (households) in the Upper Silesia Voivodeship and assessment of health risk for its consumers. To the best of our knowledge, such research in this area has not yet been carried out.

\section{Materials and methods}

\section{Sampling}

Tap water samples were taken quarterly from 18 selected locations in 8 cities (Zabrze, Bytom, Ruda Śląska, Piekary
Śląskie, Katowice, Radzionków, Sosnowiec, Mysłowice) in Silesian Voivodeship, Poland (Fig. 1. and Table 2).

Total 72 tap water samples were collected quarterly in 2019 in resident's flats, in the kitchens. The water supplier for these consumers is Upper Silesia Water Plant. The raw water comes from surface water intakes, the composition of which varies depending on the seasons. That is why the research was conducted at any time of the year (spring, summer, autumn and winter). When sampling, the tap was turned on for 2 min prior to water collection in order to discharge the residual water deposition in the pipeline; each sampling was performed in triplicate. The samples were collected in pre-cleaned HDPE bottles and transported to the laboratory after acidification with concentrated ultrapure $\mathrm{HNO}_{3}$ to $\mathrm{pH}<2$. Before acidification, the $\mathrm{pH}$ and conductivity were determined. All glassware and bottles used in the study were washed and rinsed with doubly distilled water. All chemicals used were of analytical grade, and the doubly deionized water was produced by Milli-Q-Gradient ultra-pure deionized water (Milli-QGradient ZMQ5V001, Millipore). Tap water samples were filtrated through $0.22 \mu \mathrm{m}$ PES syringe filters before analysis.

\section{Reagents}

Standard solutions were obtained by appropriate dilution of a multi-standard metals Mix 1 (Sigma-Aldrich, Switzerland), using Milli-Q-Gradient ultra-pure deionized water (Milli-QGradient ZMQ5V001, Millipore), which conductivity was $<0.05 \mu \mathrm{S} / \mathrm{cm}$. The Merck suprapure (Germany) $65 \%$ nitric acid was used for acidifying calibration solutions and samples. All standards and blank were prepared daily by using analytical balance (PX224M/1, Pioneer), directly before sample analysis. The calibration blank consisted of the acid solution was used to prepare the standards.

In order to calibrate the $\mathrm{pH}$-meter, five standard solutions (Reagecon, Ireland) with nominal values: 1.675, 4.0, 6.8, 9.225 and 12.0 were used. Two standard solutions (Reagecon, Ireland) with nominal values: $84 \mu \mathrm{S} / \mathrm{cm}$ and $12,880 \mu \mathrm{S} / \mathrm{cm}$ were used for calibration the conductometer.

\section{Apparatus}

$\mathrm{pH}$ and conductivity were determined using an InoLab IDS Multi 9310 device equipped with a pH-metric electrode IDT SenTix ${ }^{\circledR} 940$ and a conductometric sensor TetraCon 925 IDS (both from WTW, Poland) according to EN ISO 10523:2012 and EN 27888:1999 standards. The determinations of As, Co, $\mathrm{Cr}, \mathrm{Cu}, \mathrm{Mn}, \mathrm{Ni}, \mathrm{Pb}$ were carried out using a PerkinElmer inductively coupled plasma mass spectrometer ICP-MS Elan 6100 DRC-e (Shelton, USA). The operating conditions are: radio frequency power $1125 \mathrm{~W}$; plasma gas flow $15 \mathrm{~L} / \mathrm{min}$; auxiliary gas flow $0.9 \mathrm{~L} / \mathrm{min}$; lens voltage $6.5 \mathrm{~V}$. Nebulizer gas flow was optimized as needed for highest signal in the 
Table 2 Sampling points location in alphabetical order

\begin{tabular}{llll}
\hline 1 & Bytom, Estreichera St. & 10 & Radzionków, Adamieckiego St. \\
\hline 2 & Bytom, Felińskiego St. & 11 & Ruda Śląska, Kingi St. \\
3 & Bytom, Modrzewskiego St. & 12 & Ruda Śląska, Ogrodowa St. \\
4 & Bytom, Podhalańska St. & 13 & Sosnowiec, Orląt Lwowskich St. \\
5 & Katowice, Cicha St. & 14 & Zabrze, 3-th Maja St. \\
6 & Katowice, Marcina St. & 15 & Zabrze, Damrota St. \\
7 & Mysłowice-Wesoła, Norwida St. & 16 & Zabrze, Sikorskiego St. \\
8 & Piekary Śląskie, Jana Ludygi St. & 17 & Zabrze, Tuwima St. \\
9 & Piekary Śląskie, Ogrodowa St. & 18 & Zabrze, Tyska St. \\
\hline
\end{tabular}

range of $0.78-0.82 \mathrm{~L} / \mathrm{min}$. The instrument effectiveness was checked daily before measuring samples by measuring an optimization solution (Elan $6100 \mathrm{Setup} / \mathrm{Stab}$./Masscal) with a concentration $10 \mu \mathrm{g} / \mathrm{L}$ of appropriate elements $(\mathrm{Mg}, \mathrm{Cu}$, $\mathrm{Rh}, \mathrm{Cd}, \mathrm{In}, \mathrm{Ba}, \mathrm{Ce}, \mathrm{Pb}, \mathrm{U}$ ) in $1 \% \mathrm{HNO}_{3}$. In order to minimalize matrix effects, standards, blanks and samples were measured using ${ }^{103} \mathrm{Rh}$ as internal standard. Solution of $10 \mu \mathrm{g} / \mathrm{L} \mathrm{Rh}$ was added to all solutions and samples on line, by teeing in tubing on peristaltic pump.

The concentration of $\mathrm{Zn}$ and $\mathrm{Sr}$ were determined using ICP-OES inductively coupled optical emission spectrometry (Avio 200 - Perkin Elmer), according to ISO 11885:2009. The instrumental parameters were: plasma gas flow $-10 \mathrm{~L} / \mathrm{min}$; auxiliary gas flow - $0.2 \mathrm{~L} / \mathrm{min}$; nebulizer gas flow - $0.6 \mathrm{~L} / \mathrm{min}$; radio frequency power - $1400 \mathrm{~W}$; pump flow $-1.0 \mathrm{~mL} / \mathrm{min}$.

All standards and blank were prepared daily by using analytical balance, directly before sample analysis. The calibration blank consisted of the acid solution was used to prepare the standards. The validation methodology for the analyzed metals was based on the standard addition method. The recovery was determined by measuring real samples to which a known analyte amount was added. Limits of detection

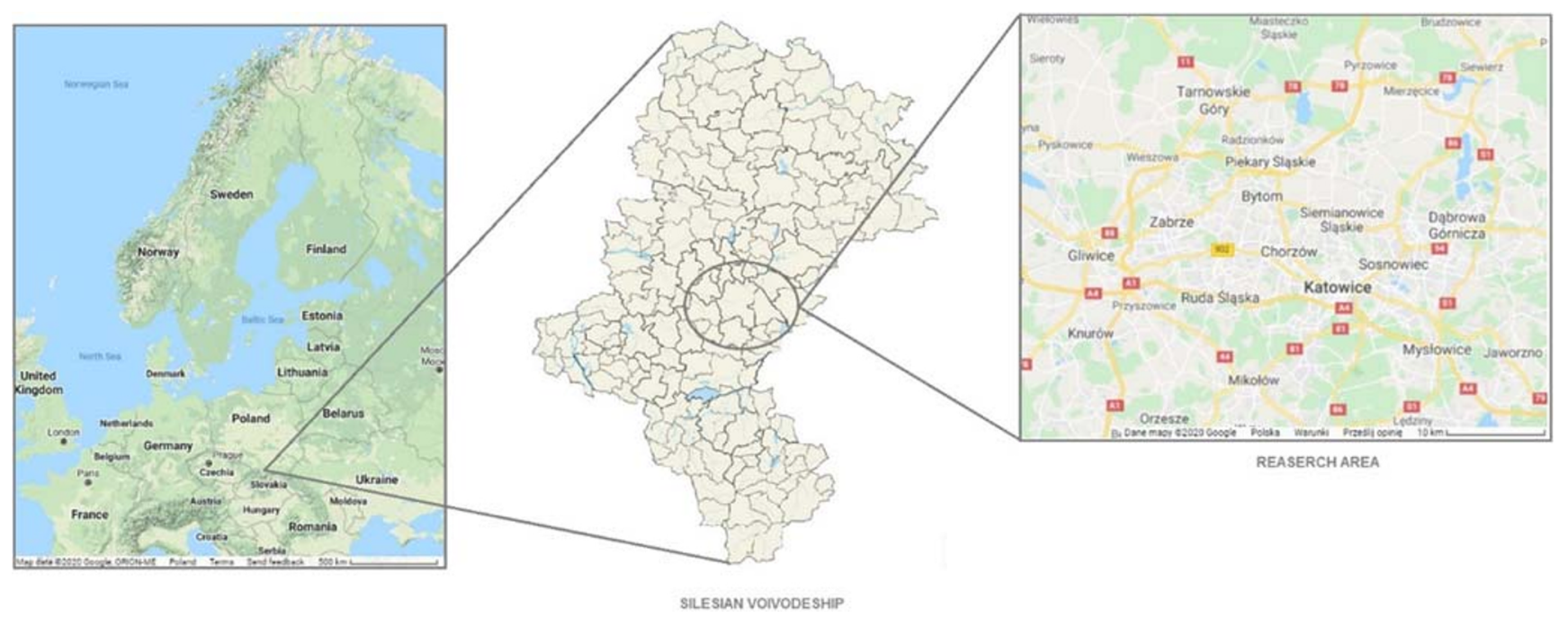

Fig. 1 Study area and sampling points [16-18]
(LOD) were calculated from calibration curves of analyzed metals (Table 3 ) and were based on the following relationship:

where: $S_{d}$ - standard deviation value, $b$ - the slope of the calibration curve.

\section{Health risk assessment}

Health risk assessment as a result of exposure to the chemical substance is the process consisting of four stages: hazard identification, exposure assessment, dose-response assessment, and risk characterization. The basis for the exposure assessment is to determine the intake dose. The Chronic Daily Intake $(\mathrm{CDI}, \mathrm{mg} / \mathrm{kg} \times$ day) was calculated using following equation:

$\mathrm{CDI}=\mathrm{C} \frac{\mathrm{CR} \times \mathrm{EF} \times \mathrm{ED}}{\mathrm{BW} \times \mathrm{AT}}$

where: $\mathrm{C}$ - average concentration of metals at exposure, $\mathrm{mg} / \mathrm{L} ; \mathrm{CR}$ - contact rate, L/day; EF - exposure frequency,
$\mathrm{LOD}=\frac{3.3 \times \mathrm{S}_{\mathrm{d}}}{\mathrm{b}}$ 
Table 3 LOD for selected metals

\begin{tabular}{ll}
\hline Metal & LOD,$\mu \mathrm{g} / \mathrm{L}$ \\
\hline $\mathrm{Mn}$ & 0.20 \\
$\mathrm{Co}$ & 0.01 \\
$\mathrm{Ni}$ & 0.14 \\
$\mathrm{~Pb}$ & 0.21 \\
$\mathrm{As}$ & 0.58 \\
$\mathrm{Cr}$ & 0.08 \\
$\mathrm{Cu}$ & 0.38 \\
$\mathrm{Sr}$ & 10 \\
$\mathrm{Zn}$ & 50 \\
\hline
\end{tabular}

days per year; ED - exposure duration, years; BW - body weight, kg; AT - period over which exposure is averaged, days.

In Table 4 the values of parameters for CDI calculation are reported.

Non-carcinogenic health risk assessment is based on the Hazard Quotient (HQ), which was calculated using equation:

$\mathrm{HQ}=\frac{\mathrm{CDI}_{\text {non-carcinogenic }}}{\mathrm{RFD}}$

where RFD is the Reference Dose Factor [mg/kg/day].

The Hazard Index (HI) is the sum of the HQ and is calculated when several metal(loid)s are studied; the critical value for HQ and $\mathrm{HI}$ is 1.

The individual excess lifetime cancer risk (IELCR) is calculated for carcinogenic substances using equation:

$\mathrm{IELCR}=\mathrm{CDI}_{\text {carcinogenic }} \times \mathrm{SF}$

Where SF is Slope Factor ( $\mathrm{mg} / \mathrm{kg} /$ day).

Total IELCR is calculated when several carcinogenic metal(loid)s are studied. The critical value for IELCR and total IELCR is $10^{-6}$.

Table 4 Human health risk assessment - the values of parameters for calculation $[16,19]$

\begin{tabular}{llll}
\hline Parameter & \multicolumn{2}{l}{ Value } & \\
\cline { 2 - 3 } & $\begin{array}{l}\text { Non-carcinogenic } \\
\text { risk assessment }\end{array}$ & Carcinogenic risk assessment \\
\cline { 2 - 3 } & Adult & Child & \\
\hline CR, L/day & 2 & 1 & 2 \\
EF, days per year & 365 & & \\
ED, years & 30 & 6 & 70 \\
BW, kg & 70 & 15 & 70 \\
AT, days & ED $\times 365$ & & \\
\hline
\end{tabular}

The RFD and CF values were acquired from: The Risk Assessment Information System, Provisional Peer-Reviewed Toxicity Values Assessments, US EPA Integrated Risk Information System, 2018 Edition of the Drinking Water Standards and Health Advisories Tables [26-28].

\section{Results and discussion \\ Conductivity, $\mathrm{pH}$, and metals concentration in analyzed tap water}

The conductivity and $\mathrm{pH}$ range in tap water samples are given in Table 5; the measured values were compliant with limit values, recommended for drinking water by Polish regulation, WHO, and US EPA.

Due to the very large number of results obtained $(4 \times 18$ samples $\times 9$ elements $=648$ analyzes) on Fig. 2 . are shown the minimum and maximum values and median values for all metals determined. For results below the detection limit, the half-LOD value method was used to create the graphs. The median concentration of selected metals in examined tap water, were as follow: $\mathrm{Sr}(260)>\mathrm{Zn}(133)>\mathrm{Cu}(23.1)>$ $\operatorname{Mn}(4.21)>\mathrm{Ni}(2.85)>\operatorname{As}(0.85)>\mathrm{Pb}(0.75)>\mathrm{Cr}(0.60)>$ $\mathrm{Co}(0.11), \mu \mathrm{g} / \mathrm{L}$. The obtained results of individual metals concentrations present a wide range of values: As $<0.58$ $1.84 \mu \mathrm{g} / \mathrm{L}$, Co $2.71-4.50 \mu \mathrm{g} / \mathrm{L}, \mathrm{Cu} 2.71-754 \mu \mathrm{g} / \mathrm{L}, \mathrm{Cr}$ $<0.08-1.78 \mu \mathrm{g} / \mathrm{L}$, Mn $0.35-39.6 \mu \mathrm{g} / \mathrm{L}$, Ni $1.06-12.6 \mu \mathrm{g} / \mathrm{L}$, $\mathrm{Pb}<0.21-12.6 \mu \mathrm{g} / \mathrm{L}, \mathrm{Sr} 89.0-720 \mu \mathrm{g} / \mathrm{L}$. In addition $75 \%$ results for As was under LOD level. These broad concentration ranges for individual metals correspond to various sources of water supply for residents of individual cities and even parts of them. With regard to legal regulations (Table 1), it was found that the concentration of $\mathrm{As}, \mathrm{Cr}, \mathrm{Cu}, \mathrm{Mn}$ and $\mathrm{Ni}$ in tap water meets the requirements. For $\mathrm{Pb}$ one of obtained values was over the WHO and Polish requirements: $12.64 \mu \mathrm{g} / \mathrm{L}$. Moreover, there are no set limits for $\mathrm{Co}, \mathrm{Sr}$ and $\mathrm{Zn}$ concentration in tap water.

\section{Health risk assessment}

The CDI, HQ and HI results for non-carcinogenic risk assessment of metals in tap water are presented in Table 6. It was observed that the CDI values of non-carcinogenic metals were higher in children than in adults. The CDI values for adults and children were found in the order of: $\mathrm{Zn}>\mathrm{Sr}>\mathrm{Cu}>\mathrm{Mn}>$ $\mathrm{Ni}>\mathrm{Pb}>\mathrm{Cr}>\mathrm{Co}>\mathrm{As}$. The risks (HQ) caused by the noncarcinogenic metals decreased in the following order: $\mathrm{Zn}>$ $\mathrm{Cu}>\mathrm{Co}>\mathrm{As}>\mathrm{Sr}>\mathrm{Pb}>\mathrm{Cr}>\mathrm{Ni}>\mathrm{Mn}$. All the studied metals had HQ values below 1 . Also HI values were less than 1. It means that the analyzed tap water is safe for human consumption. 
Table 5 Conductivity and $\mathrm{pH}$ in tap water samples

\begin{tabular}{llllll}
\hline Parameter & Unit & Range [min-max] & Mean & Median & SD \\
\hline Conductivity & $\mu \mathrm{S} / \mathrm{cm}$ & $157-794$ & 404 & 456 & 158 \\
$\mathrm{pH}$ & - & $7.34-8.39$ & 7.91 & 7.89 & 0.275 \\
\hline
\end{tabular}

The CDI, IELCR and total IELCR results for carcinogenic risk assessment of metals in tap water are presented in Table 7. The CDI values were found in the order of: $\mathrm{Pb}>\mathrm{Cr}>\mathrm{As}$. For carcinogenic substances, the acceptable threshold is $10^{-6}$. The risks caused by the carcinogenic metals decreased in the following order: $\mathrm{As}>\mathrm{Cr}>\mathrm{Pb}$, and the individual excess lifetime cancer risks were higher than $10^{-6}$ for As (1.08E-05) and $\mathrm{Cr}$ (8.54E-06). In case of chromium high IELCR value is caused by lack of the slope factor (SF) for total chromium, so for calculation SF for chromium (VI) was used. Chromium speciation analysis would be required to determine the chromium (VI) concentration in tap water samples. It could be assumed that IELCR for chromium (VI) was below $10^{-6}$. IELCR for arsenium was higher than $10^{-6}$, but concentration of As in tap water samples was below the maximum value recommended by Polish regulation, WHO, and US EPA. Total IELCR was also higher than $10^{-6}$. The US EPA considers acceptable for regulatory purposes a cancer risk in the range of $10^{-6}$ to $10^{-4}$.

\section{Discussion}

For example, Stegavik [20] tested the heavy metal pollution in the drinking water distribution network of Trondheim (Norway). The results showed that the concentrations of $\mathrm{Pb}$, $\mathrm{Cd}, \mathrm{Cu}$ and $\mathrm{Zn}$ in the drinking water have been less than the standard level, and there is no concern for the public health. Dashtizadeh et al. [21] evaluate the concentrations of: As, Cd, $\mathrm{Cr}, \mathrm{Ni}, \mathrm{Pb}, \mathrm{B}, \mathrm{Al}, \mathrm{Hg}, \mathrm{Mn}, \mathrm{Zn}, \mathrm{Cu}, \mathrm{Fe}$, Se and $\mathrm{Ba}$ in tap water of Zahedan (Iran). A total of 155 samples of drinking water were randomly taken from the tap water and were analyzed using ICP-OES device. The hazard index (HI) values for children and adult age groups were 9.84E-01 and 4.22E-01, respectively. The cumulative Excess Lifetime Cancer Risk
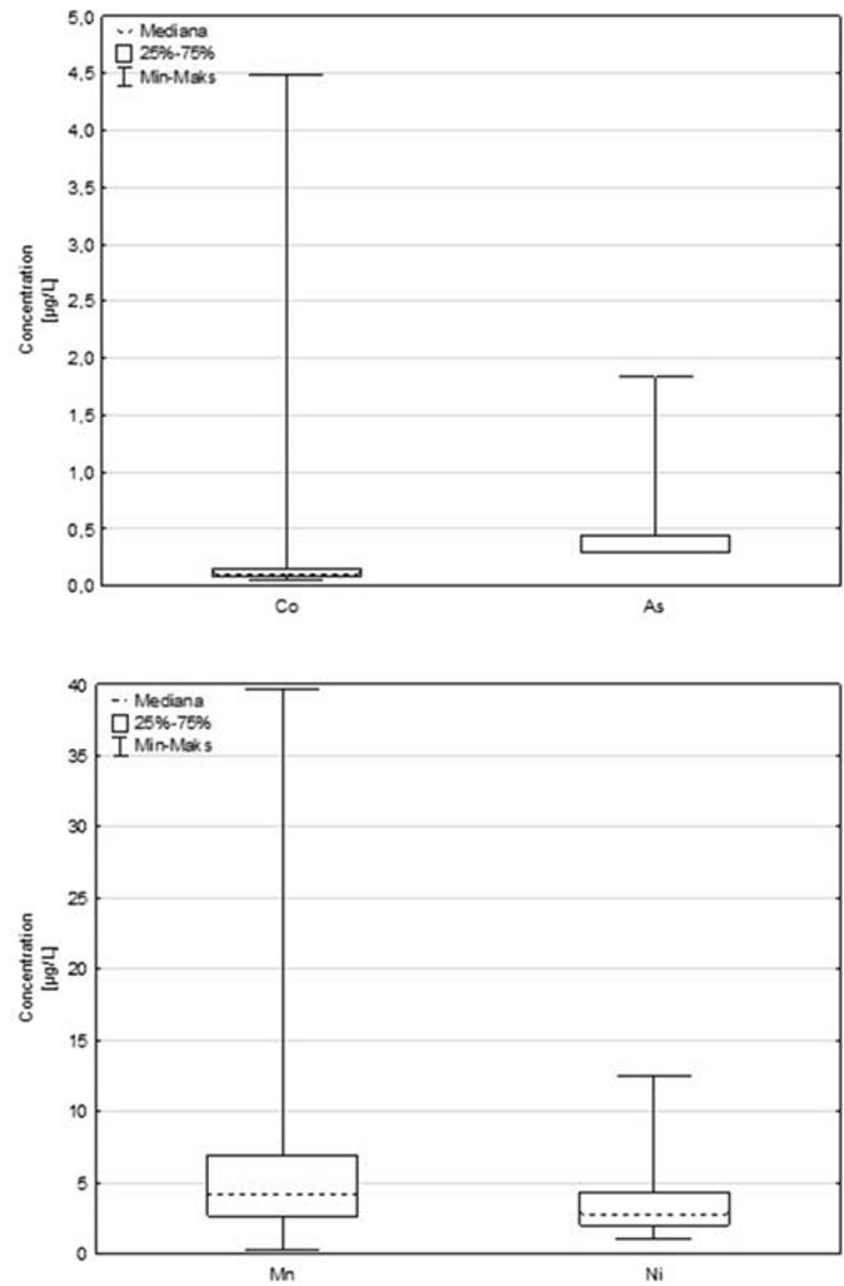

Fig. 2 Minimal and maximal concentration, and median values for selected metals in tap water sample 
Table 6 Non-carcinogenic risk of metal(loid)s in tap water

\begin{tabular}{|c|c|c|c|c|c|c|}
\hline \multirow[t]{2}{*}{ Metal } & \multirow[t]{2}{*}{ Concentration, $\mathrm{mg} / \mathrm{L}$} & \multirow[t]{2}{*}{$\mathrm{RFD}, \mathrm{mg} / \mathrm{kg} / \mathrm{day}$} & \multicolumn{2}{|c|}{$\mathrm{CDI}, \mathrm{mg} / \mathrm{kg} /$ day } & \multicolumn{2}{|l|}{ HQ } \\
\hline & & & Adult & Child & Adult & Child \\
\hline $\mathrm{Cr}$ (total) & $5.98 \mathrm{E}-04$ & $3.00 \mathrm{E}-03^{*}$ & $1.71 \mathrm{E}-05$ & $3.98 \mathrm{E}-05$ & $5.69 \mathrm{E}-03$ & $1.33 \mathrm{E}-02$ \\
\hline Co & $3.13 \mathrm{E}-04$ & $3.00 \mathrm{E}-04$ & $8.95 \mathrm{E}-06$ & $2.09 \mathrm{E}-05$ & $2.98 \mathrm{E}-02$ & $6.96 \mathrm{E}-02$ \\
\hline Mn & $5.46 \mathrm{E}-03$ & $1.40 \mathrm{E}-01$ & $1.56 \mathrm{E}-04$ & $3.64 \mathrm{E}-04$ & $1.11 \mathrm{E}-03$ & $2.60 \mathrm{E}-03$ \\
\hline $\mathrm{Cu}$ & $5.67 \mathrm{E}-02$ & $4.00 \mathrm{E}-02$ & $1.62 \mathrm{E}-03$ & $3.78 \mathrm{E}-03$ & $4.05 \mathrm{E}-02$ & $9.45 \mathrm{E}-02$ \\
\hline $\mathrm{Ni}$ & $3.67 \mathrm{E}-03$ & $2.00 \mathrm{E}-02$ & $1.05 \mathrm{E}-04$ & $2.45 \mathrm{E}-04$ & $5.24 \mathrm{E}-03$ & $1.22 \mathrm{E}-02$ \\
\hline $\mathrm{Pb}$ & $1.34 \mathrm{E}-03$ & $3.60 \mathrm{E}-03$ & $3.84 \mathrm{E}-05$ & $8.96 \mathrm{E}-05$ & $1.07 \mathrm{E}-02$ & 2.49E-02 \\
\hline As & $2.52 \mathrm{E}-04$ & $3.00 \mathrm{E}-04$ & 7.19E-06 & $1.68 \mathrm{E}-05$ & $2.40 \mathrm{E}-02$ & $5.59 \mathrm{E}-02$ \\
\hline $\mathrm{Zn}$ & $5.00 \mathrm{E}-01$ & $3.00 \mathrm{E}-01$ & $1.43 \mathrm{E}-02$ & $3.33 \mathrm{E}-02$ & $4.76 \mathrm{E}-02$ & $1.11 \mathrm{E}-01$ \\
\hline \multirow[t]{2}{*}{$\mathrm{Sr}$} & $3.05 \mathrm{E}-01$ & $6.00 \mathrm{E}-01$ & $8.71 \mathrm{E}-03$ & $2.03 \mathrm{E}-02$ & $1.45 \mathrm{E}-02$ & $3.39 \mathrm{E}-02$ \\
\hline & & $\mathrm{HI}=\sum \mathrm{HQ}_{\mathrm{i}}$ & & & $1.79 \mathrm{E}-01$ & 4.18E-01 \\
\hline
\end{tabular}

${ }^{*}$ RFD for chromium (VI) [29]
(ELCR) for carcinogenic trace elements was in range of tolerable carcinogenic risk $10^{-6}$ to $10^{-4}$. Another study from Iran, reported by Sarvestani and Aghasi [22], has been conducted to evaluate the concentrations of $\mathrm{Pb}, \mathrm{Cd}$ and $\mathrm{Cu}$ in 160 drinking water samples in Kerman city, Iran. The results showed that the mean concentrations of lead metal in tap water have been higher than the recommended quantity based on the standards of the WHO and USEPA. In turn, 192 different drinking water sources in Chenzhou City of Hunan Province (China) were tested by Huang et al. [23]; carcinogenic and non-carcinogenic risk assessment was performed according to the method recommended by the US EPA. One more example from China concerns 116 tap water samples from Hunan province [24]; the results showed that $10 \%$ of the water samples exceeded the limit level of Cd established by WHO $\left(0.003 \mathrm{mg} \mathrm{L}^{-1}\right), 3 \%$ of the samples had Fe level and $1 \%$ had As level above the WHO limits $\left(0.3\right.$ and $\left.0.01 \mathrm{mg} \mathrm{L}^{-1}\right)$, respectively. In the central area of Mexico, where the underground water was contaminated by natural origin arsenic and fluoride [25], in order to estimate health risk associated with human exposure to these pollutants, tap water samples from the southern-central region of the state were analyzed; $90 \%$ of the samples exceeded the levels of arsenic established by the WHO. The results of the conducted research are comparable with the data published by other authors cited in this work.

\section{Study limitation}

Our research was limited to 18 metals and one year. A further limitation is that the interactions between different contaminants were not investigated as it would require a good knowledge of the mechanisms of toxicity for the different compounds. Recently, we are continuing them in a wider analytical scope (inorganic anions and cations as well as additional metals and metalloids), as well as sampling points (30 points, including water from other water suppliers).

\section{Conclusion}

The wide range of concentration very probably origin from the erosion of sediment or corrosion of pipes and fittings used in the urban plumbing systems. The cumulative cancer risk of the target heavy metals for the children and adults using the tap water and bottled water are within the acceptable monitored and controlled levels $\left(10^{-4}-10^{-6}\right)$. It was observed that the CDI values of non-carcinogenic metals were higher in children than in adults. The CDI values for adults and children were found in the order of: $\mathrm{Zn}>\mathrm{Sr}>\mathrm{Cu}>\mathrm{Mn}>\mathrm{Ni}>\mathrm{Pb}>$ $\mathrm{Cr}>\mathrm{Co}>\mathrm{As}$. The risks (HQ) caused by the noncarcinogenic metals decreased in the following order: $\mathrm{Zn}>$ $\mathrm{Cu}>\mathrm{Co}>\mathrm{As}>\mathrm{Sr}>\mathrm{Pb}>\mathrm{Cr}>\mathrm{Ni}>\mathrm{Mn}$. All the studied
Table 7 Carcinogenic risk of metals in tap water

\begin{tabular}{lllll}
\hline Metal & Concentration, mg/L & CDI, mg/kg/day & SF, mg/kg/day & IELCR, mg/kg $\times$ day \\
\hline $\mathrm{Cr}$ (total) & $5.98 \mathrm{E}-04$ & $1.71 \mathrm{E}-05$ & $5.00 \mathrm{E}-01^{*}$ & $8.54 \mathrm{E}-06$ \\
$\mathrm{~Pb}$ & $1.34 \mathrm{E}-03$ & $3.84 \mathrm{E}-05$ & $8.50 \mathrm{E}-03$ & $3.27 \mathrm{E}-07$ \\
$\mathrm{As}$ & $2.52 \mathrm{E}-04$ & $7.19 \mathrm{E}-06$ & $1.50 \mathrm{E}+00$ & $1.08 \mathrm{E}-05$ \\
$\sum$ IELCR & & & & $1.96 \mathrm{E}-05$ \\
\hline
\end{tabular}

*SF for chromium (VI) 
metals had HQ values below 1. Also HI values were less than 1. It means that the analyzed tap water is safe for human consumption. No significant seasonal changes in the concentrations of the tested metals were found. This proves the stability of the water and benefits its consumers. Although there is no potential health risk for children and adults, the children group consuming the tap water is at the risk of noncarcinogenic adverse health effect. Thus, it is recommended that the metals and metalloids concentrations should be periodically monitored more widely than official requirements to minimize the health risks in consumers.

Acknowledgments The authors would like to thank to EkoEnergia Water - Security Technology Park in Katowice for financial support for this work.

\section{Authors' contributions}

- Rajmund Michalski: work concept, manuscript writing, proofreading, calculations, discussion of results, English.

- Paulina Pecyna-Utylska: work concept, health risk calculations, tables, proofreading, discussion of results.

- Joanna Kernert: Calculations, tables, figures, proofreading, references, - Katarzyna Grygoyć: Analysis (ICP-MS, ICP-OES), discussion of results.

- Justyna Klyta: Analysis (ICP-MS, ICP-OES), discussion of results.

Funding The authors would like to thank to EkoEnergia - Water Security Technology Park in Katowice for financial support for this work.

Data availability Not applicable.

Conflicts of interest/competing interests The authors confirm no conflicts of interest associated with this publication.

Code availability Not applicable.

Open Access This article is licensed under a Creative Commons Attribution 4.0 International License, which permits use, sharing, adaptation, distribution and reproduction in any medium or format, as long as you give appropriate credit to the original author(s) and the source, provide a link to the Creative Commons licence, and indicate if changes were made. The images or other third party material in this article are included in the article's Creative Commons licence, unless indicated otherwise in a credit line to the material. If material is not included in the article's Creative Commons licence and your intended use is not permitted by statutory regulation or exceeds the permitted use, you will need to obtain permission directly from the copyright holder. To view a copy of this licence, visit http://creativecommons.org/licenses/by/4.0/.

\section{References}

1. Kavcar P, Sofuoglu A, Sofuoglu SC. A health risk assessment for exposure to trace metals via drinking water ingestion pathway. Int $\mathrm{J}$ Hyg Environ Health. 2009;212:216-27. https://doi.org/10.1016/j. ijheh.2008.05.002.

2. Su CC. Heavy metal and cancer risk. J Public Health Epidemiology. 2015;1(4):1019-21.
3. Reynolds KA, Mena KD, Gerba CP. Risk of waterborne illness via drinking water in the United States. In: Whitacre DM, editor. Reviews of environmental contamination and toxicology. Berlin: Springer: 2008. pp. 117-158.

4. Quevauviller P, Thompson KC. Analytical methods for drinking water: advances in sampling and analysis. Ltd: John Wiley \& Sons; 2005.

5. Crompton TR. Determination of metals in natural waters, sediments, and soils. New York: Elsevier; 2015.

6. Michalski R. Hyphenated methods for speciation snalysis. In: Wiley J, editor. Meyers RA. John Wiley \& Sons, Ltd.: Encyclopedia of analytical chemistry. Chichester; 2019. p. 1-20.

7. Michalski R. Application of IC-MS and IC-ICP-MS in Environmental research. New Jersey: John Wiley \& Sons, Inc. Hoboken; 2016.

8. World Health Organization. Guidelines for drinking-water quality, 4th edition, incorporating the 1st addendum, 2017.

9. Office of Water U.S. Environmental Protection Agency. 2018 Edition of the drinking water standards and health advisories. March 2018. https://www.epa.gov/sites/production/files/2018-03/ documents/dwtable2018.pdf

10. Regulation of the Minister of Health of December 7, 2017 regarding the quality of water intended for human consumption, JL 2017 item 2294.

11. Michalski R, Jabłońska M, Szopa S, Łyko A. Application of ion chromatography with ICP-MS or MS detection to the determination of selected halides and metal/metalloids species. Crit Rev Anal Chem. 2011;41:133-50. https://doi.org/10.1080/10408347.2011. 559438.

12. Jaishankar M, Tseten T, Anbalagan N, Mathew BB, Beeregowda $\mathrm{KN}$. Toxicity, mechanism and health effects of some heavy metals. Interdiscip Toxicol. 2014; https://doi.org/10.2478/intox-20140009.

13. Colak EH, Yomralioglu T, Nisanci R, Yildirim V. Duran C Geostatistical analysis of the relationship between heavy metals in drinking water and cancer incidence in residential areas in the Black Sea region of Turkey. J Environ Health. 2015;77(6):86-93.

14. Michalski R, Kostecki M, Kernert J, Pecyna P, Jabłońska - Czapla M, Grygoyć K, Nocoń K. Time and spatial variability in concentrations of selected metals and their species in water and bottom sediments of Dzierżno Duże (Poland). J Environ Sci Health, Part A, Toxic/Hazard Subst Environ Eng. 2019; https://doi.org/10.1080/ 10934529.2019.1592530

15. Michalski R, Jabłońska-Czapla J, Szopa S, Łyko A, Grygoyć K. Variability in different antimony, arsenic and chromium species in waters and bottom sediments of three water reservoirs in upper Silesia (Poland): a comparative study. Int J Environ Anal Chem. 2016;96:682-93. https://doi.org/10.1080/03067319.2016. 1180382 .

16. https://www.google.pl/maps/@ 49.8657946,13.0994544,4.5z/ data $=! 5 \mathrm{ml} ! 1 \mathrm{e} 4$ ?hl=en. Accessed 4 Apr 2020.

17. https://pl.wikipedia.org/wiki/Plik:Slaskie_mapa_administracyjna. png. Accessed 4 Apr 2020.

18. https://www.google.pl/maps/@ 50.3860943,19.1293402,10z. Accessed 4 Apr 2020.

19. Environmental Protection Agency EPA. Risk Assessment Guidance for Superfund, vol. I. Part A: Human Health Evaluation Manual; 1989. https://www.epa.gov/sites/production/files/201509/documents/rags_a.pdf

20. Stegavik K. An investigation of heavy metal contamination of drinking water in the city of Trondheim, Norway. Bull Environ Contam Toxicol (1975)14:57-60.

21. Dashtizadeh M, Kamani H, Ashrafi SD, Panahi AH, Mahvi AH, Balarak D, et al. Human health risk assessment of trace elements in drinking tap water in Zahedan city. Iran J Environ Health Sci Eng. 2019;17:1163-9. https://doi.org/10.1007/s40201-019-00430-6. 
22. Sarvestani RA, Aghasi M. Health risk assessment of heavy metals exposure (lead, cadmium, and copper) through drinking water consumption in Kerman city. Iran Environ Earth Sci. 2019;78. https:// doi.org/10.1007/s12665-019-8723-0.

23. Huang X, He L, Li J, Yang F, Tan H. Different choices of drinking water source and different health risks in a rural population living near a lead/zinc mine in Chenzhou City, southern China. Int $\mathrm{J}$ Environ Res Public Health. 2015;12:14364-81. https://oi.org/10. 3390/ijerph121114364.

24. Li M, Du Y, Chen L, Liu L, Duan Y. Assessment of trace elements in terminal tap water of Hunan Province, South China, and the potential health risks. Environ Monit Assess. 2018;190:318. https://doi.org/10.1007/s10661-018-6684-5.

25. Martínez-Acuña MI, Mercado-Reyes M, Alegría-Torres JA, MejíaSaavedra JJ. Preliminary human health risk assessment of arsenic and fluoride in tap water from Zacatecas. México Environ Monit Assess. 2016;188. https://doi.org/10.1007/s10661-016-5453-6.
26. The Risk Assessment Information System https://rais.ornl.gov/cgibin/tools/TOX_search?select=chemtox. Accessed 14 Apr 2020.

27. Provisional Peer-Reviewed Toxicity Values (PPRTVs) Assessments https://www.epa.gov/pprtv/provisional-peerreviewed-toxicity-values-pprtvs-assessments. Accessed 14 Apr 2020.

28. Integrated Risk Information System (IRIS) Assessments https:// cfpub.epa.gov/ncea/iris_drafts/atoz.cfm. Accessed 14 Apr 2020.

29. Sun H, Brocato J, Costa M., Oral chromium exposure and toxicity Curr Envir Health Rpt 2015; https://doi.org/10.1007/s40572-0150054-z

Publisher's note Springer Nature remains neutral with regard to jurisdictional claims in published maps and institutional affiliations. 